\title{
Successful pregnancy after complete resection of leiomyomatosis peritonealis disseminate without recurrence: A case report with next generation sequencing analysis and literature review
}

Hualei Bu

Qilu Hospital of Shandong University

Chengjuan Jin

Shanghai General Hospital

Yan Fang

Qilu Hospital of Shandong University

Yana Ma

Qilu Hospital of Shandong University

Xiao Wang

Qilu Hospital of Shandong University

Jingying Chen

Shandong University Qilu Hospital

Lijun Chen ( $\nabla$ qlijunchen@163.com )

Shandong University Qilu Hospital https://orcid.org/0000-0002-6048-7434

\section{Case report}

Keywords: LPD, NGS, pregnancy, Leiomyosarcoma

Posted Date: February 12th, 2020

DOI: https://doi.org/10.21203/rs.2.23395/v1

License: (c) (i) This work is licensed under a Creative Commons Attribution 4.0 International License. Read Full License

Version of Record: A version of this preprint was published at World Journal of Surgical Oncology on May 2nd, 2020. See the published version at https://doi.org/10.1186/s12957-020-01857-0. 


\section{Abstract}

Background: Peritoneal leiomyomatosis disseminate (LPD) is a rare disease characterized by widespread dissemination of leiomyomas nodules throughout the peritoneal and omental surfaces. Reports of pregnancy with LPD are even rarer. Therefore, there is no clear consensus on the treatment of LPD on pregnancy, and the pathogenesis is still unclear.

Case presentation $\varangle$ We reported a case of LPD patient who developed during pregnancy. The patient underwent cesarean section at 32 weeks of gestation while removing all visible tumors, and no LPD lesions were seen in the subsequently cesarean section at full-term. NGS of LPD lesions detected 4 mutations with focal high-level amplifications of CDK4 (Cyclin-dependent kinases 4), NBN (Nibrin), DAXX (Death domain associated protein) and MYC (Myelocytomatosis oncogene). Immunohistochemistry staining analysis among benign leiomyoma, LPD and leiomyosarcoma verified that LPD was an unusual intermediate between benign and malignant uterine smooth muscle tumors. Besides, LPD is a hormonal-dependent leiomyoma. After detailed literature search, we summarized the detailed clinical features and follow-up information of patients with LPD during pregnancy.

Conclusions: This is the first reported LPD case of successful term pregnancy without recurrence, following resection of all visible lesions in prior pregnancy. LPD is an unusual intermediate between benign and malignant uterine smooth muscle tumors.

\section{Introduction}

Uterine smooth muscle tumors include a variety of tumors, such as benign uterine leiomyoma, malignant leiomyosarcoma and tumors with unusual growth patterns. Uterine leiomyoma is the most common tumor of the female reproductive system[1]. Benign leiomyoma variants mainly include atypical leiomyoma, plexiform leiomyoma, cellular leiomyoma, smooth muscle tumor of uncertain malignant potential[2]. Leiomyosarcoma is uterine malignancy with an aggressive clinical behavior and poor prognosis. Leiomyosarcoma distinguishes from uterine leiomyoma by the presence of coagulative tumor necrosis, severe cellular atypia, extreme cytogenetic instability and elevated mitotic activity[3]. LPD as well as intravenous leiomyomatosis belongs to a class of tumors resembling uterine leiomyoma at both gross and microscopic levels but presenting in unusual locations with recurrent and malignant tendencies[4].

LPD is a rare benign intra-abdominal leiomyoma characterized by multifocal proliferation of smooth muscle-like cells that are histologically similar to uterine leiomyoma[5, 6]. Up to date, there have been no more than 200 cases published, of which approximately half been reported in child-bearing years and only few cases in postmenopausal women[7-9]. LPD lesions always involve the pelvic, the abdominal peritoneum and the omentum. The patients generally presents with no clinical symptoms, however, abdominal pain or abdominal distension do occasionally occur[10]. Clinical examination usually reveals numerous smooth muscle nodules in pelvic, the abdominal peritoneum and the omentum. Histopathology examination suggests benign uterine smooth muscle tumors, rare mitotic activity, without nuclear atypia[11].

However, there is still no standardized guideline for the diagnosis and treatment of LPD. LPD occurs during pregnancy is even rarer, so the treatment is even more uncertain. After a detailed literature research, we summarized 15 articles that reported detailed characteristics of LPD during pregnancy, with a total of 16 patients[9, 12-25], which was seen in Table 1. Most patients did not achieve complete lesion resection, but LPD lesions were significantly reduced or disappeared after delivery, and no recurrence occurred during follow-up. Among the patients with a history 
of LPD with re-pregnancy, only 2 cases have been reported in the literature. In one case[23], LPD was present before pregnancy, and the lesion increased rapidly in a short time after receiving assisted reproductive technology, and radical surgery (hysterectomy and bilateral adnexectomy) was performed at 10+ week gestation. Another patient was diagnosed with LPD during the first trimester to full-term cesarean section, but only biopsy was performed, and LPD recurred during the second trimester[18]. Because of the limited number of patients, we are still very confused about the treatment of LPD during pregnancy, and it is still unknown whether patients with a history of LPD can get pregnant again, which makes it very difficult for clinicians to make decision.

\section{Case Presentation}

\subsection{Case}

A 19-year-old woman with $32^{+3}$ weeks of gestation was referred to our hospital due to oligohydramnios. The patient had a history of myomectomy at age 15. At that time of ultrasound examination, there was a mass of $20.0 \mathrm{~cm} * 8.7$ $\mathrm{cm}$ in size in the pelvic cavity. Postoperative pathological findings showed cellular uterine leiomyoma.

On admission, both the patient and the fetus were in good condition. Physical examination revealed huge mass in pelvic cavity. Abdominal and pelvic ultrasound confirmed the presence of multiple masses in pelvic, sized $16.9 * 11.2 * 10.1 \mathrm{~cm}, 13.1 * 5.6 * 6.2 \mathrm{~cm}, 19.2 * 17.5 * 12 \mathrm{~cm}$ respectively next to the gestation without signs of abortion. The masses were connected into large clumps. Abdominal MRI was done to show multiple nodules in the abdominal cavity (Figure 1).

In order to ascertain the diagnosis, an exploratory laparotomy was performed because of aggravated abdominal pain. After delivery the fetus by lower-segment cesarean section, the gynecological oncologist performed further operation. The patient was found to have multiple sporadic leiomyoma in anterior wall of uterus, an $8 * 6 \mathrm{~cm}$ leiomyoma in posterior wall of uterus, a $20 * 15 \mathrm{~cm}$ tumor mass in the left pelvis, multiple tumor masses in the right pelvic sized $8 * 7 \mathrm{~cm}, 7 * 7 \mathrm{~cm}$ and $7 * 5 \mathrm{~cm}$ separately, up to 10 tumor masses sized $3 * 2 \mathrm{~cm}$ in omentum and mesocolon transversum (Figure2 A-D). All macroscopic tumor masses were dissected and removed via an extremely difficult surgery without hysterectomy and bilateral salpingo-oophorectomy because of the patient's strong objection and the consideration of young age. Post-operative pathology determined the diagnosis of LPD with red degeneration. The patient recovered well after surgery and was discharged on the ninth day after removal of the abdominal incision suture.

The patient underwent several ultrasound examinations after surgery and no signs of disease recurrence were found without any continuous treatment. The patient was pregnant again 25 months after the surgery. At 7 weeks of gestation, ultrasound examination revealed a fibroid of about $3.7 \mathrm{~cm} \star 3.7 \mathrm{~cm}$ in the posterior wall of the uterus, and ultrasound examination during pregnancy indicated that the fibroid was slowly enlarged without any discomfort symptoms. The patient underwent cesarean section again at 39 weeks of gestation. No abnormal lesions were found in the pelvic and abdominal cavity during the operation, and only a uterine fibroid of about $7 \mathrm{~cm} * 6 \mathrm{~cm}$ was found in the posterior wall of the uterus (Figure $2 \mathrm{E}$ ). Postoperative pathology suggested uterine leiomyoma. The patient was reviewed at 6 months postoperatively and recovered well.

\subsection{NGS (next generation sequencing)}

We collected 15 of $4 \mu \mathrm{m}$ tissue sections from FFPE samples of LPD and normal tissue adjacent to the lesion for the genetic analyses. QIAamp DNA FFPE Tissue Kit (QIAGEN, Heidelberg, Germany) was used to extract genomic DNA 
according to the manufacturer's instructions.

DNA was profiled using a commercial available capture-based targeted sequencing panel (Burning Rock Biotech Ltd, Guangzhou, China), targeting 295 genes which were closely related to the mechanism of cancer and targeted therapy and spanning 1.5MB of Human genomic regions. DNA shearing, end repair and adaptor ligation was performed by the use of Covaris M220 (Covaris, Inc., MA, US). Fragment sizes ranging from 200bp to 400bp were selected using Agencourt AMPure beads (Beckman Coulter, CA, US) followed by hybridization with capture probes baits, hybrid selection with magnetic beads and PCR amplification. Subsequently, Qubit® 3.0 and Agilent 2100 bioanalyzer (Agilent Technologies Inc., CA, US) was performed to assess the quality and size of the fragments. Indexed samples were sequenced on Nextseq500 sequencer (Illumina, Inc., CA, US) with pair-end reads.

Based on the high throughput sequencing, the copy numbers (CNs) of this LPD patient compared with normal population were demonstrated in Figure 3G. There were four somatic cell lines mutations detected in the lesions. The CNs of CDK4, NBN, DAXX and MYC were all amplified for at least 4 times.

\subsection{Hematoxylin-eosin (HE) and immunohistochemistry staining}

Hematoxylin-eosin (HE) staining slides of this LPD were shown in Figure 3A. Rich blood supply was revealed in LPD in HE staining analysis (Figure 3B).

Immunohistochemistry staining showed that the tumor was strongly positive for smooth muscle markers, SMA and Desmin (Figure 3C, 3D), which suggested that LPD shared partial molecular cytogenetic characteristics with uterine leiomyoma. Immunohistochemistry of hormone receptors, estrogen receptor (ER) and progesterone receptor (PR) were positive (Figure 3E, 3F).

The immunohistochemistry staining analysis of CDK4, MYC, NBN and DAXX in uterine leiomyoma (10 cases), LPD (4 cases) and leiomyosarcoma (10 cases) revealed that the expression profiles of LPD were more similar to leiomyosarcoma. LPD showed CDK4, NBN, DAXX, MYC moderately and strongly positive and uterine leiomyosarcoma displayed strongly positive. However, the four markers in uterine leiomyoma were slightly positive or negative. Therefore, we can infer the conclusion that LPD is an intermediate disease between benign uterine fibroids and malignant leiomyosarcoma.

\section{Discussion And Conclusions}

In 1952, Willson and Peale described LPD for the first time[6]. LPD characterized with multiple nodules in various sizes in peritoneal cavity, such as uterus, fallopian tubes, intestine, mesentery, omentum and retroperitoneum[6]. The incidence of LPD was unkown due to its rarity. There have been no more than 200 cases reported in the literature up to date.

LPD was difficult to diagnose before surgery. Although it was a benign disease with excellent prognosis, LPD could behave quasi-malignant behavior, such as recur tendency and spread widely in pelvic and abdominal cavity. LPD should be differentiated from peritoneal metastasis of malignancies. Standard histopathological analysis as well as immunochemistry was in need to diagnose LPD accurately. Microscopically, the knots are composed of smooth muscle arranged like leiomyomas. The cells usually show a lack of atypia and higher mitotic variety[9]. In this study, the patient was suspected to have a malignant tumor in pelvic and peritoneal cavity initially. The diagnosis of LPD was confirmed until the histopathology identified. LPD must be distinguished from malignancies to avoid unnecessary aggressive treatment schedules. 
LPD predominantly occurs in females of reproductive age, however, the pathogenesis of LPD is poorly understood. Four popular theories on the pathogenesis of LPD have been mentioned earlier. High levels of estrogen and progesterone, such as oral contraceptives, pregnancy, ovarian stimulation, estrogen-producing ovarian tumors and uterine leiomyoma, have been described in most reported cases[5, 9, 17, 26-28]. In this case, high levels of estrogen and progesterone stimulation also played an essential role in the development of LPD. Pregnancy and uterine leiomyoma together exacerbated the increasing levels of estrogen and progesterone. In this LPD, the tumor cells were strongly positive for ER and PR in immunochemistry analysis, supporting the hypothesis that high levels of estrogen and progesterone playing an important role in the pathogenesis of LPD.

LPD shared some molecular cytogenetic characteristics with uterine leiomyoma, such as SMA and Desmin strongly positive in IHC analysis. The histogenesis of LPD is consistent with that of uterine leiomyoma. However, LPD differentiates distinctly from uterine leiomyoma in phenotype. Uterine leiomyoma is obviously benign, whereas LPD has the quasi-malignant behavior. NGS might provide the potential molecular explanation that would explain this difference in phenotype. Compared with common population, CNs of CDK4, MYC, NBN, DAXX were all amplified for at least 4 times in this LPD. Immunochemistry of the four genes among uterine leiomyoma, LPD and uterine leiomyosarcoma was implied. LPD and uterine leiomyosarcoma both were strong positive for the abovementioned four genes, whereas uterine leiomyoma was slightly positive or negative for the four genes. CNs mutations might play an important role in the pathogenesis mechanism of LPD and identify LPD in phenotype from uterine leiomyoma. Further study is in urgent need to delineate the molecular mechanisms underlying the LPD phenotype. In addition, some literatures have confirmed that LPD will be followed by malignant transformation[29-31]. More importantly, based on the above results, we should pay attention to the potential malignancy of LPD during the treatment and follow-up of LPD.

Most importantly, we will discuss the feasibility and safety of pregnancy in patients with LPD. The few cases reported so far do not provide conclusive evidence, and we have no guidelines to follow. After a comprehensive review of the literature, the following conclusions can be drawn: Firstly, assisted reproductive technology is not recommended for patients with LPD, which may lead to the rapid growth of lesions due to the increased estrogen level, leading to serious adverse consequences. Furthermore, complete excision of the lesion if the condition permits may prevent recurrence of the disease in the subsequent pregnancy. Unfortunately, we can only derive these inferences from only a few case reports, and we need more patients to confirm.

In conclusion, we recommend that all visible lesions should be removed as completely as possible during surgery, which may be a very effective treatment plan in addition to radical surgery, and re-pregnancy may be feasible. LPD is an unusual intermediate between benign and malignant uterine smooth muscle tumors.

\section{Declarations}

Ethics approval and consent to participate[Ethical approval was obtained from Ethics Committee of Shandong University, and written informed consent was obtained from each patient.

Consent for publication[Consent for publication of this case was obtained.

Availability of data and materials: All data generated or analysed during this study are included in this published article.

Competing interests: The authors declare that they have no competing interests 
Funding: This work was supported by grants from the Department of Medical and Health Science Technology of Shandong province [project numbers: 2016WS0345], and from the National Natural Science Foundation of China [project numbers: 81602286].

Authors' contributions: $\mathrm{BH}$ and JC conducted the experiment and wrote the manuscript. FY, CJ and MY reviewed the literature. WX conducted the IHC analysis. CL was the attending physician of the patient. All authors read and approved the final manuscript.

Acknowledgements: Not applicable.

\section{References}

1. Bulun SE: Uterine fibroids.N Engl J Med 2013, 369:1344-1355.

2. Evans HL, Chawla SP, Simpson C, Finn KP: Smooth muscle neoplasms of the uterus other than ordinary leiomyoma. A study of 46 cases, with emphasis on diagnostic criteria and prognostic factors.Cancer 1988, 62:2239-2247.

3. Fletcher JA, Morton CC, Pavelka K, Lage JM: Chromosome aberrations in uterine smooth muscle tumors: potential diagnostic relevance of cytogenetic instability.Cancer Res 1990, 50:4092-4097.

4. Marrone G, Crino F, Morsolini M, Caruso S, Miraglia R: Multidisciplinary approach in the management of uterine intravenous leiomyomatosis with intracardiac extension: case report and review of literature.J Radiol Case Rep 2019, 13:1-13.

5. Takeda T, Masuhara K, Kamiura S: Successful management of a leiomyomatosis peritonealis disseminata with an aromatase inhibitor.Obstet Gynecol 2008, 112:491-493.

6. Willson JR, Peale AR: Multiple peritoneal leiomyomas associated with a granulosa-cell tumor of the ovary. $A m \mathrm{~J}$ Obstet Gynecol 1952, 64:204-208.

7. Halama N, Grauling-Halama SA, Daboul I: Familial clustering of Leiomyomatosis peritonealis disseminata: an unknown genetic syndrome? BMC Gastroenterol 2005, 5:33.

8. Rajab KE, Aradi AN, Datta BN: Postmenopausal leimyomatosis peritonealis disseminata.Int J Gynaecol Obstet 2000, 68:271-272.

9. Summa B, Schem C, Weigel M, Strauss A, Jonat W, Maass N, Schafer F, Bauerschlag DO: Leiomyomatosis peritonealis disseminata in a pregnant woman.Arch Gynecol Obstet 2010, 281:123-127.

10. Yang R, Xu T, Fu Y, Cui S, Yang S, Cui M: Leiomyomatosis peritonealis disseminata associated with endometriosis: A case report and review of the literature. Oncol Lett 2015, 9:717-720.

11. Gaichies L, Fabre-Monplaisir L, Fauvet R, Alves A, Mulliri A: Leiomyomatosis peritonealisis disseminata: Two unusual cases with literature review.J Gynecol Obstet Hum Reprod 2018, 47:89-94.

12. Hardman WJ, 3rd, Majmudar B: Leiomyomatosis peritonealis disseminata: clinicopathologic analysis of five cases.South Med J 1996, 89:291-294.

13. Aterman K, Fraser GM, Lea RH: Disseminated peritoneal leiomyomatosis. Virchows Arch A Pathol Anat Histol 1977, 374:13-26.

14. Tanaka YO, Tsunoda H, Sugano M, Satoh T, Yagi H, Minami R, Shiigai M, Inadome Y, Yoshikawa H, Noguchi M, Minami M: MR and CT findings of leiomyomatosis peritonealis disseminata with emphasis on assisted reproductive technology as a risk factor.Br J Radiol 2009, 82:e44-47. 
15. Valente PT, Fine BA, Parra C, Schroeder B: Gastric stromal tumor with peritoneal nodules in pregnancy: tumor spread or rare variant of diffuse leiomyomatosis.Gynecol Oncol 1996, 63:392-397.

16. Rubin SC, Wheeler JE, Mikuta JJ: Malignant leiomyomatosis peritonealis disseminata.Obstet Gyneco/ 1986, 68:126-130.

17. Dreyer L, Simson IW, Sevenster CB, Dittrich OC: Leiomyomatosis peritonealis disseminata. A report of two cases and a review of the literature. Br J Obstet Gynaeco/ 1985, 92:856-861.

18. Lim OW, Segal A, Ziel HK: Leiomyomatosis peritonealis disseminata associated with pregnancy.Obstet Gynecol 1980, 55:122-125.

19. Pieslor PC, Orenstein JM, Hogan DL, Breslow A: Ultrastructure of myofibroblasts and decidualized cells in leiomyomatosis peritonealis disseminata.Am J Clin Pathol 1979, 72:875-882.

20. Nogales FF, Jr., Matilla A, Carrascal E: Leiomyomatosis peritonealis disseminata. An ultrastructural study. Am J Clin Pathol 1978, 69:452-457.

21. Parmley $\mathrm{TH}$, Woodruff JD, Winn K, Johnson JW, Douglas $\mathrm{PH}$ : Histogenesis of leiomyomatosis peritonealis disseminata (disseminated fibrosing deciduosis). Obstet Gynecol 1975, 46:511-516.

22. Crosland DB: Leiomyomatosis peritonealis disseminata: a case report.Am J Obstet Gynecol 1973, 117:179-181.

23. Deering S, Miller B, Kopelman JN, Reed M: Recurrent leiomyomatosis peritonealis disseminata exacerbated by in vitro fertilization.Am J Obstet Gynecol 2000, 182:725-726.

24. Kouakou F, Adjoby R, Gondo D, Loue V, N'Guessan K, Kouame A, Effoh D: Leiomyomatosis peritonealis disseminata and pregnancy: a case report.Clin Exp Obstet Gynecol 2012, 39:541-543.

25. Hoynck van Papendrecht HP, Gratama S: Leiomyomatosis peritonealis disseminata.Eur J Obstet Gynecol Reprod Biol 1983, 14:251-259.

26. Tavassoli FA, Norris HJ: Peritoneal leiomyomatosis (leiomyomatosis peritonealis disseminata): a clinicopathologic study of 20 cases with ultrastructural observations.Int J Gynecol Pathol 1982, 1:59-74.

27. Kumar S, Sharma JB, Verma D, Gupta P, Roy KK, Malhotra N: Disseminated peritoneal leiomyomatosis: an unusual complication of laparoscopic myomectomy.Arch Gynecol Obstet 2008, 278:93-95.

28. Thian YL, Tan KH, Kwek JW, Wang J, Chern B, Yam KL: Leiomyomatosis peritonealis disseminata and subcutaneous myoma-a rare complication of laparoscopic myomectomy.Abdom Imaging 2009, 34:235-238.

29. Chiu HC, Wu MY, Li CH, Huang SC, Yiang GT, Yen HS, Liu WL, Li CJ, Kao WY: Epithelial-Mesenchymal Transition with Malignant Transformation Leading Multiple Metastasis from Disseminated Peritoneal Leiomyomatosis.J Clin Med 2018, 7.

30. Syed M, Parida B, Mankeshwar T, Patil A: Imaging Findings in a Rare Case of Leiomyomatosis Peritonealis Disseminata with Malignant Transformation.Pol J Radiol 2017, 82:426-430.

31. Rettenmaier M, Epstein HD, Abaid LN, Bechtol KA, Goldstein BH: Leiomyosarcoma with synchronous clear cell ovarian carcinoma.Onkologie 2010, 33:695-697.

\section{Table}

\section{Table 1 The summary of LPD cases occurring during pregnancy}

\section{Figures}




\begin{tabular}{|c|c|c|c|c|c|c|c|}
\hline Author & Age & $\begin{array}{l}\text { History of } \\
\text { hysteromy- } \\
\text { omectomy }\end{array}$ & $\begin{array}{l}\text { Gestational } \\
\text { weeks }\end{array}$ & Complications & $\begin{array}{l}\text { Operative } \\
\text { methods }\end{array}$ & $\begin{array}{c}\text { Surgical } \\
\text { investigation }\end{array}$ & Follow-up \\
\hline $\begin{array}{l}\text { Summa } \\
\mathrm{B}^{9}\end{array}$ & 29 & No & $22^{+6}$ & $\begin{array}{l}\text { Abdominal } \\
\text { emergency }\end{array}$ & $\begin{array}{c}\text { Explorative } \\
\text { laparotomy and } \\
\text { partial nodule } \\
\text { resection }\left(22^{+6} \mathrm{w}\right) \\
\text { Cesarean } \\
\text { section }\left(28^{+6} \mathrm{w}\right)\end{array}$ & $\begin{array}{l}\text { Nodules up to } \\
7.3 \mathrm{~cm} \text { on } \\
\text { omentum } \\
\text { minus, } \\
\text { appendices } \\
\text { epiploicae, } \\
\text { the colon, } \\
\text { right adnexa } \\
\text { and uterus. }\end{array}$ & $\begin{array}{l}\text { Nodules } \\
\text { spontaneously } \\
\text { subsided, and } \\
\text { no recurrence } \\
1 \text { year after } \\
\text { operation. }\end{array}$ \\
\hline $\begin{array}{c}\text { Hardman } \\
\text { WJ } 12\end{array}$ & 33 & No & 36 & $\begin{array}{l}\text { Premature } \\
\text { rupture of } \\
\text { membrane }\end{array}$ & $\begin{array}{c}\text { Cesarean section } \\
\text { and omental } \\
\text { biopsies }\end{array}$ & $\begin{array}{c}\text { Multiple firm, } \\
\text { round, white- } \\
\text { togray } \\
\text { omental } \\
\text { nodules, sized } \\
0.5 * 08 * 1.5 \mathrm{~cm} \\
\text { to } \\
1.5 * 3 * 3.5 \mathrm{~cm}\end{array}$ & $\begin{array}{l}\text { No signs of } \\
\text { tumor growth } \\
\text { during } 43 \\
\text { months of } \\
\text { follow-up. }\end{array}$ \\
\hline $\begin{array}{l}\text { Hardman } \\
\text { WJ } 12\end{array}$ & 36 & No & $38^{+5}$ & $\begin{array}{l}\text { Placenta } \\
\text { previa }\end{array}$ & $\begin{array}{c}\text { Cesarean section } \\
\text { and omental } \\
\text { biopsies }\end{array}$ & $\begin{array}{c}\text { Multiple firm, } \\
\text { round, white- } \\
\text { togray } \\
\text { omental } \\
\text { nodules, sized } \\
0.5 * 08 * 1.5 \mathrm{~cm} \\
\text { to } \\
1.5 * 3 * 3.5 \mathrm{~cm}\end{array}$ & $\begin{array}{l}\text { No signs of } \\
\text { tumor growth } \\
\text { during } 146 \\
\text { months of } \\
\text { follow-up. }\end{array}$ \\
\hline Aterman ${ }^{13}$ & 22 & Yes & Full term & Fetal distress & $\begin{array}{c}\text { Cesarean section } \\
\text { and noodles } \\
\text { biopsies }\end{array}$ & $\begin{array}{l}\text { Firm nodules } \\
\text { of variable } \\
\text { size on } \\
\text { omentum, } \\
\text { bowel and } \\
\text { the capsule of } \\
\text { liver. }\end{array}$ & $\begin{array}{l}\text { Nodules were } \\
\text { significantly } \\
\text { reduced } 4 \\
\text { months after } \\
\text { surgery. }\end{array}$ \\
\hline TANAK $^{14}$ & 40 & Yes & Unknown & $\begin{array}{c}\text { IVF-ET } \\
\text { twin } \\
\text { pregnancy }\end{array}$ & $\begin{array}{l}\text { Cesarean section } \\
\text { and nodules } \\
\text { biopsies }^{1 \text { st }} \text {. } \\
\text { Hysterectomy and } \\
\text { tuberculectomy } \\
\text { 2nd }\end{array}$ & $\begin{array}{l}\text { Nodules in } \\
\text { peritoneal } \\
\text { cavity and } \\
\text { both inguinal } \\
\text { regions }{ }^{1 \mathrm{st}} \\
\text { a large } \\
\text { tumor within } \\
\text { the right } \\
\text { broad } \\
\text { ligament and } \\
\text { numerous } \\
\text { nodules in } \\
\text { peritoneal } \\
\text { cavity }^{2 n d} \\
\end{array}$ & $\begin{array}{c}\text { Recurrence } \\
\text { occurred } 8 \\
\text { months after } \\
\text { the } 1 \text { st } \\
\text { surgery, and } \\
\text { no recurrence } \\
18 \text { months } \\
\text { after } 2^{\text {nd }} \\
\text { surgery }\end{array}$ \\
\hline PHILIP 15 & 32 & No & 28 & $\begin{array}{c}\text { Abdominal } \\
\text { pain, ascites }\end{array}$ & $\begin{array}{c}\text { Explorative } \\
\text { laparotomy and } \\
\text { cesarean section }\end{array}$ & $\begin{array}{l}\text { A large cystic } \\
\text { mass arised } \\
\text { from the } \\
\text { lesser } \\
\text { curvature of } \\
\text { the stomach, } \\
\text { and multiple } \\
\text { nodules on } \\
\text { peritoneal } \\
\text { surfaces, } 2 \text { to } \\
3 \text { mm in size. }\end{array}$ & $\begin{array}{c}\text { No intra- } \\
\text { abdominal } \\
\text { masses were } \\
\text { shown on CT } \\
9 \text { months } \\
\text { after surgery. }\end{array}$ \\
\hline Rubin $^{16}$ & 27 & No & Full term & $\begin{array}{c}\text { Active phase } \\
\text { arrest }\end{array}$ & $\begin{array}{l}\text { Cesarean section } \\
\text { and partial nodule } \\
\text { resection }\end{array}$ & $\begin{array}{l}\text { Multiple firm, } \\
\text { rubbery } \\
\text { nodules } \\
\text { scattered } \\
\text { throughout } \\
\text { the pelvic } \\
\text { and } \\
\text { omentum }\end{array}$ & $\begin{array}{c}\text { Bone } \\
\text { metastasis } \\
\text { was found } 6 \\
\text { months after } \\
\text { surgery, and } \\
\text { sarcoma was } \\
\text { diagnosed. }\end{array}$ \\
\hline Dreyer $^{17}$ & 26 & Unknown & Full term & $\begin{array}{c}\text { Vulval } \\
\text { haematoma }\end{array}$ & $\begin{array}{l}\text { Explorative } \\
\text { laparotomy }\end{array}$ & $\begin{array}{c}\text { Numerous } \\
\text { small nodules } \\
\text { on the } \\
\text { uterine } \\
\text { serosa, the } \\
\text { serosa of the } \\
\text { bowel, the }\end{array}$ & Lost \\
\hline
\end{tabular}


omentum and

parietal

peritoneum

\begin{tabular}{|c|c|c|c|c|c|c|c|}
\hline $\operatorname{Lim}^{18}$ & 22 & Unknown & $\begin{array}{l}\text { Full } \\
\text { term }{ }^{1 \text { st }} \\
35+2 \text { nd }\end{array}$ & $\begin{array}{l}\text { Premature } \\
\text { rupture of } \\
\text { membrane }\end{array}$ & $\begin{array}{l}\text { Cesarean section } \\
\text { and noodles } \\
\text { biopsies }^{1 \text { st and } 2 \text { nd }}\end{array}$ & $\begin{array}{l}\text { Uterus, lower } \\
\text { abdomen and } \\
\quad \text { cul-de-sac } \\
\text { were studded } \\
\text { with nodules } \\
\text { ranged from } \\
\quad 0.25 \text { to } \\
\quad 3 \mathrm{~cm}^{1 \text { st }} \\
\text { Mesentery, } \\
\text { omentum and } \\
\text { the liver } \\
\text { surface were } \\
\text { studded with } \\
\text { nodules of } \\
\text { massive size } \\
\text { and numbers } \\
\text { num }\end{array}$ & $\begin{array}{c}\text { Asymptomatic } \\
\text { clinical course } \\
8 \text { month after } \\
2^{\text {nd }} \text { surgery }\end{array}$ \\
\hline Pieslor $^{19}$ & 32 & No & Full term & No & Cesarean section & $\begin{array}{c}\text { A short } \\
\text { omentum } \\
\text { replaced by } \\
\text { nodules of } \\
\text { firm whitish } \\
\text { tissue 3-9 } \\
\text { mm in } \\
\text { diameter, the } \\
\text { bladder was } \\
\text { covered by } \\
\text { numerous 1- } \\
\text { mm white } \\
\text { nodules. }\end{array}$ & Unknown \\
\hline Nogales $^{2}$ & 34 & Unknown & Full term & $\begin{array}{l}\text { Prolonged } \\
\text { labor }\end{array}$ & $\begin{array}{c}\text { Cesarean section, } \\
\text { total hysterectomy } \\
\text { and } \\
\text { partial nodule } \\
\text { resection }\end{array}$ & $\begin{array}{c}\text { Widely } \\
\text { scattered } \\
\text { white firm } \\
\text { nodules on } \\
\text { uterine } \\
\text { surface, both } \\
\text { broad } \\
\text { ligaments, } \\
\text { cul-de-sac, } \\
\text { omentum, } \\
\text { bowel, } \\
\text { mesentery } \\
\text { and } \\
\text { peritoneum }\end{array}$ & Unknown \\
\hline Parmley $^{21 .}$ & 36 & Unknown & Full term & No & $\begin{array}{l}\text { Elective tubal } \\
\text { ligation }\end{array}$ & $\begin{array}{c}\text { Multiple, } \\
\text { small, firm, } \\
\text { white nodules } \\
\text { noted on the } \\
\text { anterior } \\
\text { surface of the } \\
\text { uterus, small } \\
\text { bowel and } \\
\text { peritoneum. }\end{array}$ & $\begin{array}{l}\text { No evidence } \\
\text { of intra- } \\
\text { peritoneal } \\
\text { neoplasia } 2 \\
\text { years after } \\
\text { surgery }\end{array}$ \\
\hline Crosland $^{22}$ & 29 & Unknown & 8 & $\begin{array}{c}\text { Severe } \\
\text { hypertension }\end{array}$ & $\begin{array}{l}\text { suction curettage } \\
\text { and omentectomy }\end{array}$ & $\begin{array}{l}0.2 \text { to } 2.5 \mathrm{~cm} \\
\text { nodulations } \\
\text { on all } \\
\text { abdominal } \\
\text { and pelvic } \\
\text { organs and } \\
\text { peritoneum }\end{array}$ & $\begin{array}{c}\text { Nodules } \\
\text { decreased in } \\
\text { size without } \\
\text { detailed } \\
\text { months } \\
\text { provided }\end{array}$ \\
\hline Deering $^{23}$ & 33 & LPD & $10+$ & $\begin{array}{c}\text { IVF-ET } \\
\text { abdominal } \\
\text { pain }\end{array}$ & $\begin{array}{l}\text { hysterectomy, } \\
\text { bilateral salpingo- } \\
\text { oophorectomy, } \\
\text { radical pelvic } \\
\text { lymph nodes } \\
\text { dissection }\end{array}$ & $\begin{array}{l}\text { The nodules } \\
\text { grew rapidly } \\
\text { after IVF-ET, } \\
\text { reaching a } \\
\text { maximum of } \\
\text { about } 17 \mathrm{~cm} \text {, } \\
\text { and did not } \\
\text { shrink after } \\
\text { termination } \\
\text { of pregnancy. }\end{array}$ & $\begin{array}{l}9 \text { months } \\
\text { without } \\
\text { recurrence } \\
\text { after surgery }\end{array}$ \\
\hline Kouakou $^{24}$ & 35 & No & Full term & $\begin{array}{l}\text { Large fetus } \\
\text { size }\end{array}$ & $\begin{array}{l}\text { Cesarean section } \\
\text { and omental }\end{array}$ & $\begin{array}{l}\text { Multitude } \\
\text { nodules }\end{array}$ & $\begin{array}{l}\text { Postoperative } \\
\text { consultation } 6\end{array}$ \\
\hline
\end{tabular}




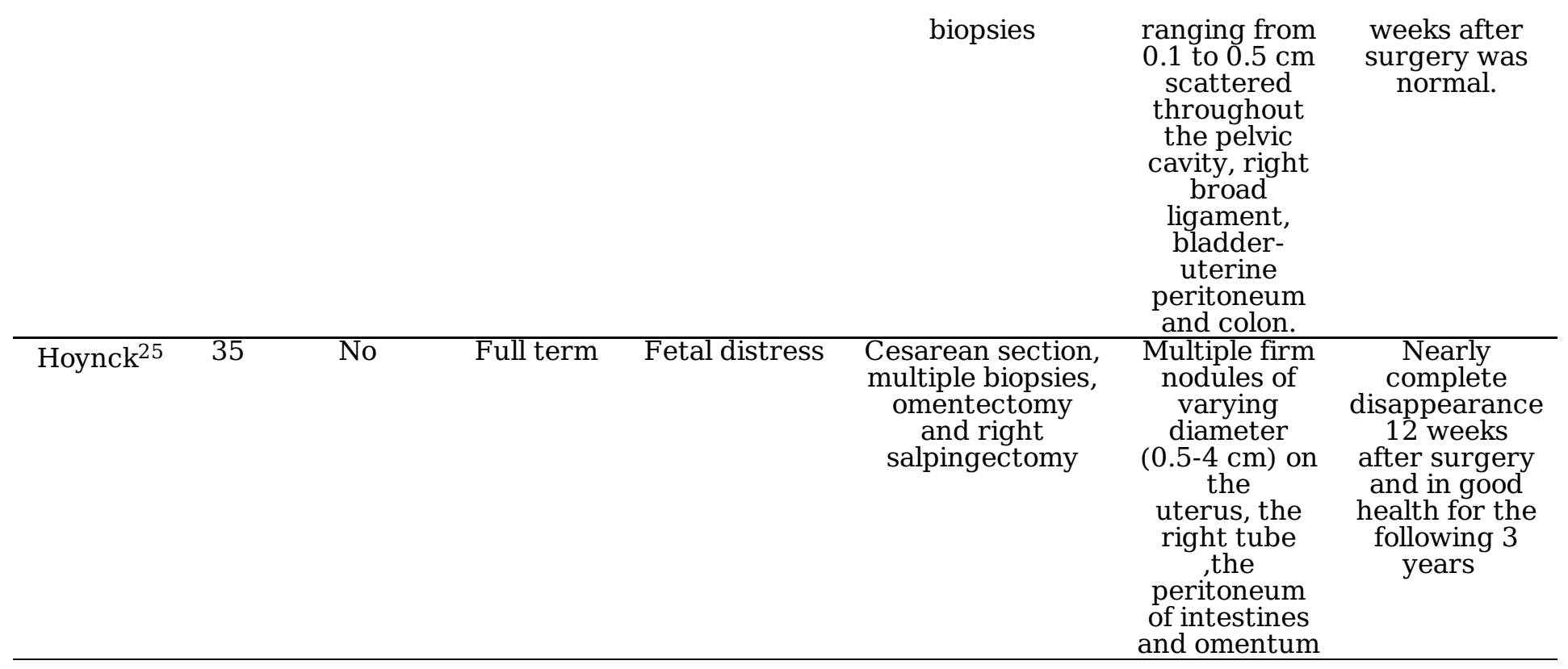

A

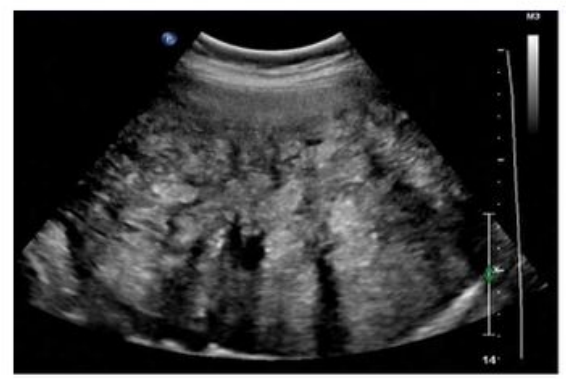

D

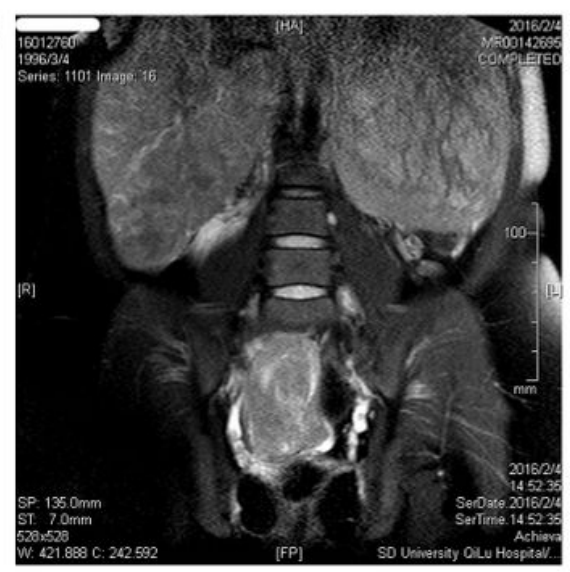

B

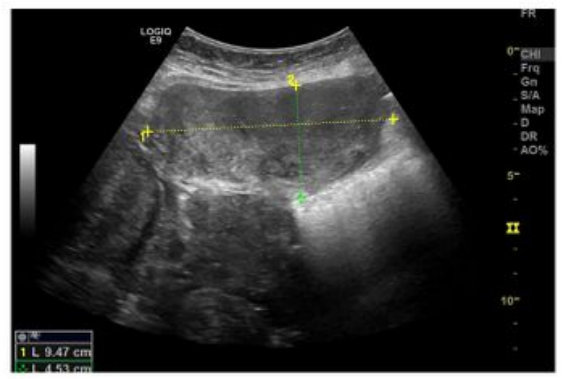

$\mathrm{E}$

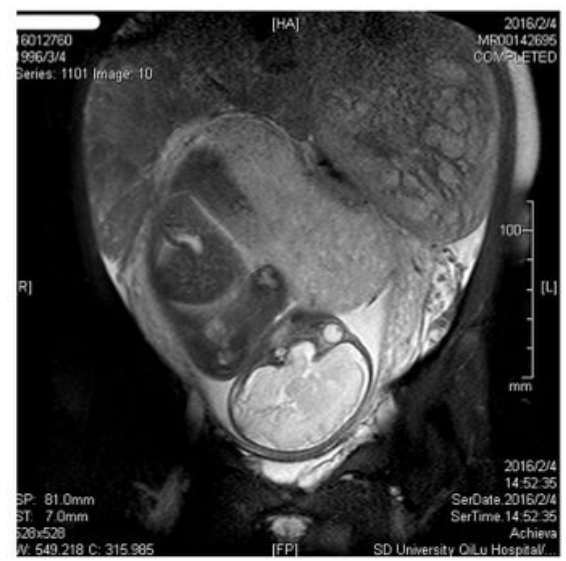

C

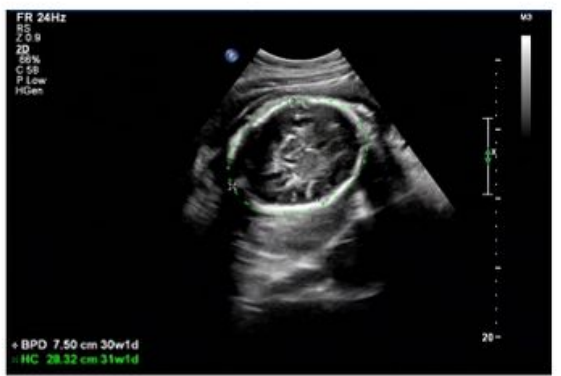

$F$

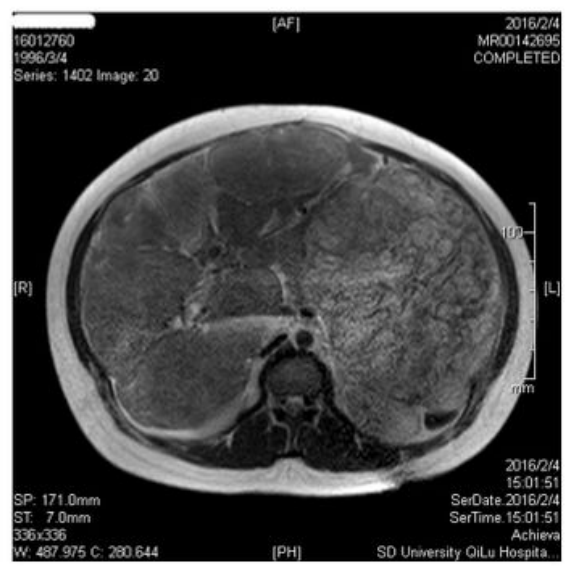

Figure 1

Ultrasound and MRI showed the presence of multiple masses in the pelvis. (A, B) Ultrasound showed huge mass in the pelvis. (C) Fetal head in ultrasound. (D) Multiple huge masses in the pelvis were shown in MRI. (E-F) The fetal was squeezed by huge masses in MRI. 
A

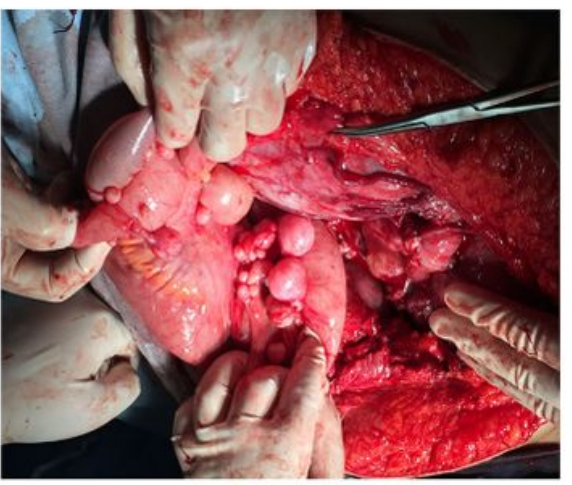

D

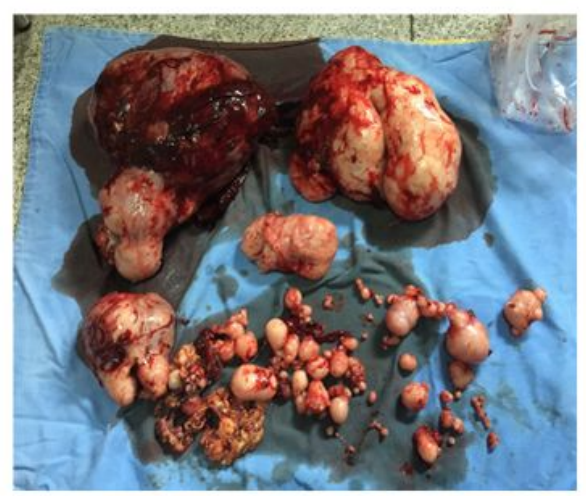

B

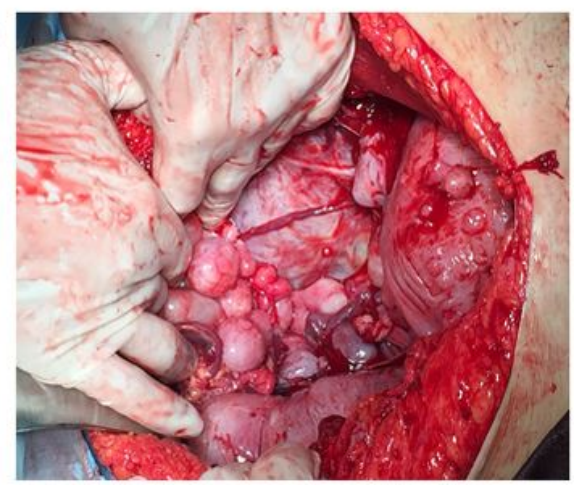

E

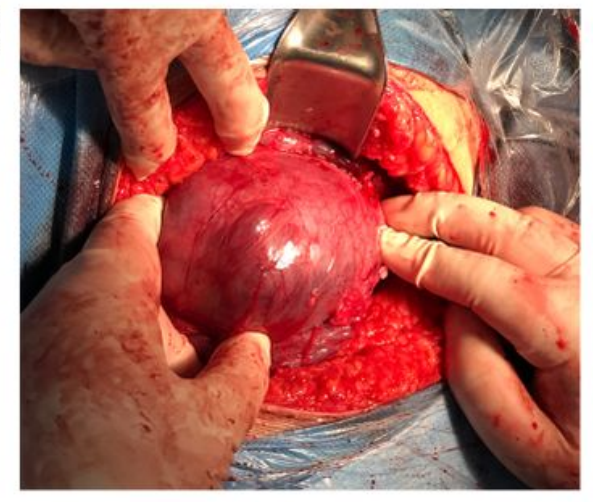

C

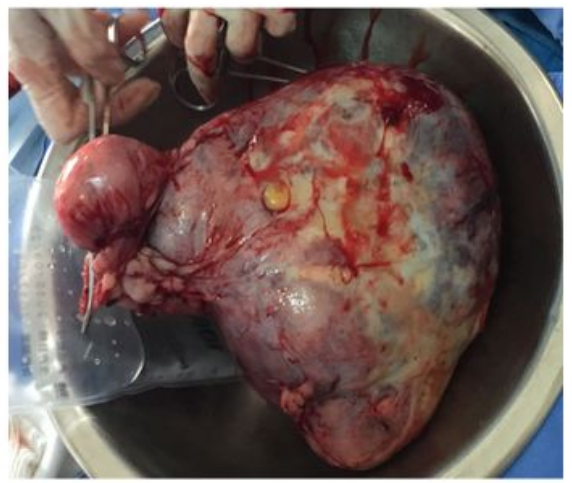

$\mathbf{F}$

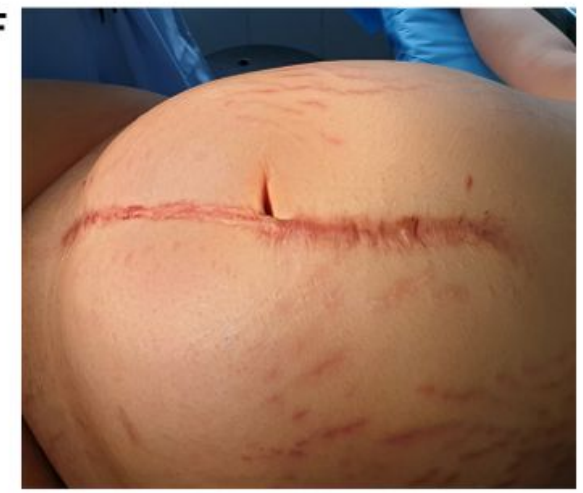

\section{Figure 2}

Gross features of LPD during laparotomy. (A-B) Concentrated myoma tubercle like cysts on the surface of the uterine, the intestine and mesentery. (C) The resected huge myoma. (D) All myomas removed in laparotomy, two large myomas, two moderate myomas and multiple small myomas. (E) A single uterine fibroid was found in the posterior wall of the uterus in the second cesarean section. (F) Abdominal scar of the first cesarean section. 

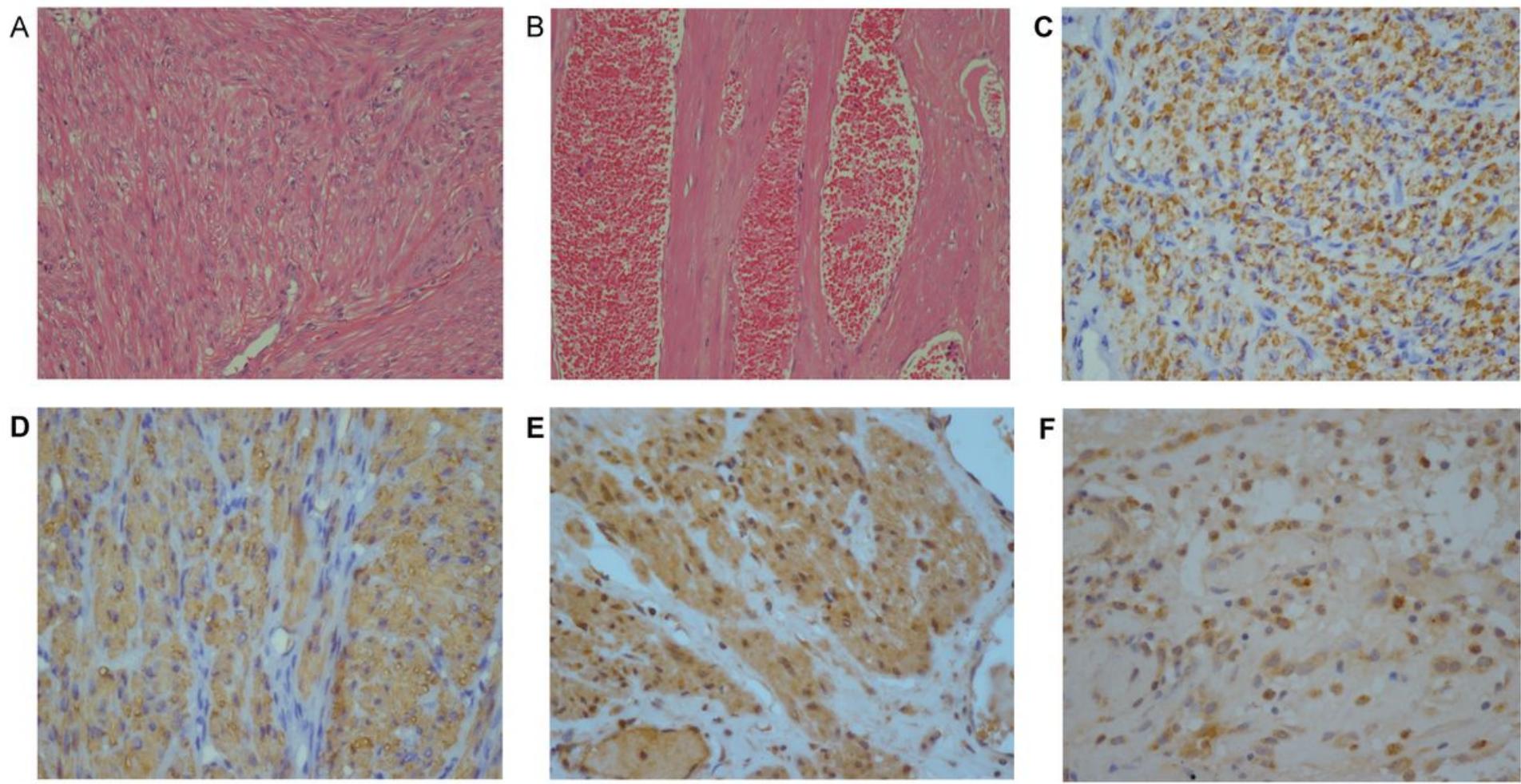

G

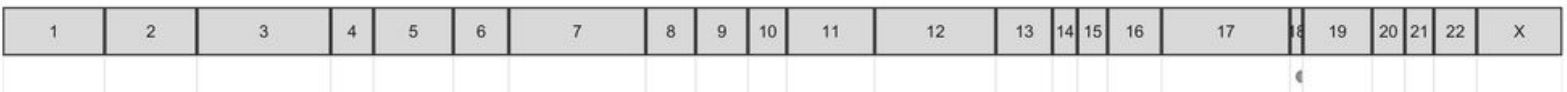
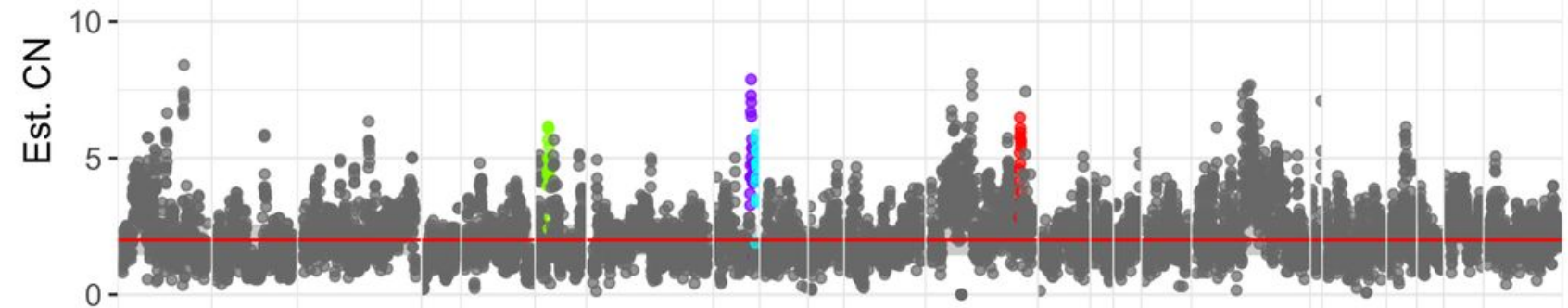

- CDK4

- DAXX

- MYC

- NBN

- N.S

\section{Figure 3}

HE staining and immunohistochemistry analysis of LPD. (A-B) HE staining of this LPD, suggesting benign myoma with rich blood supply. (C) Immunohistochemistry staining of Desmin, 40x. (D) Immunohistochemistry staining of SMA, 40x. (E) Immunohistochemistry of estrogen receptor (ER), 40x. ER was strongly positive in LPD. (F) Immunohistochemistry of progesterone receptor (PR), 40x. PR was strongly positive in LPD. (G) Distribution plot of gene copy number in NGS of this LPD. CDK4, DAXX, MYC, NBN were significantly amplified (red = CDK4, green = DAXX, blue $=$ MYC, purple $=$ NBN). 

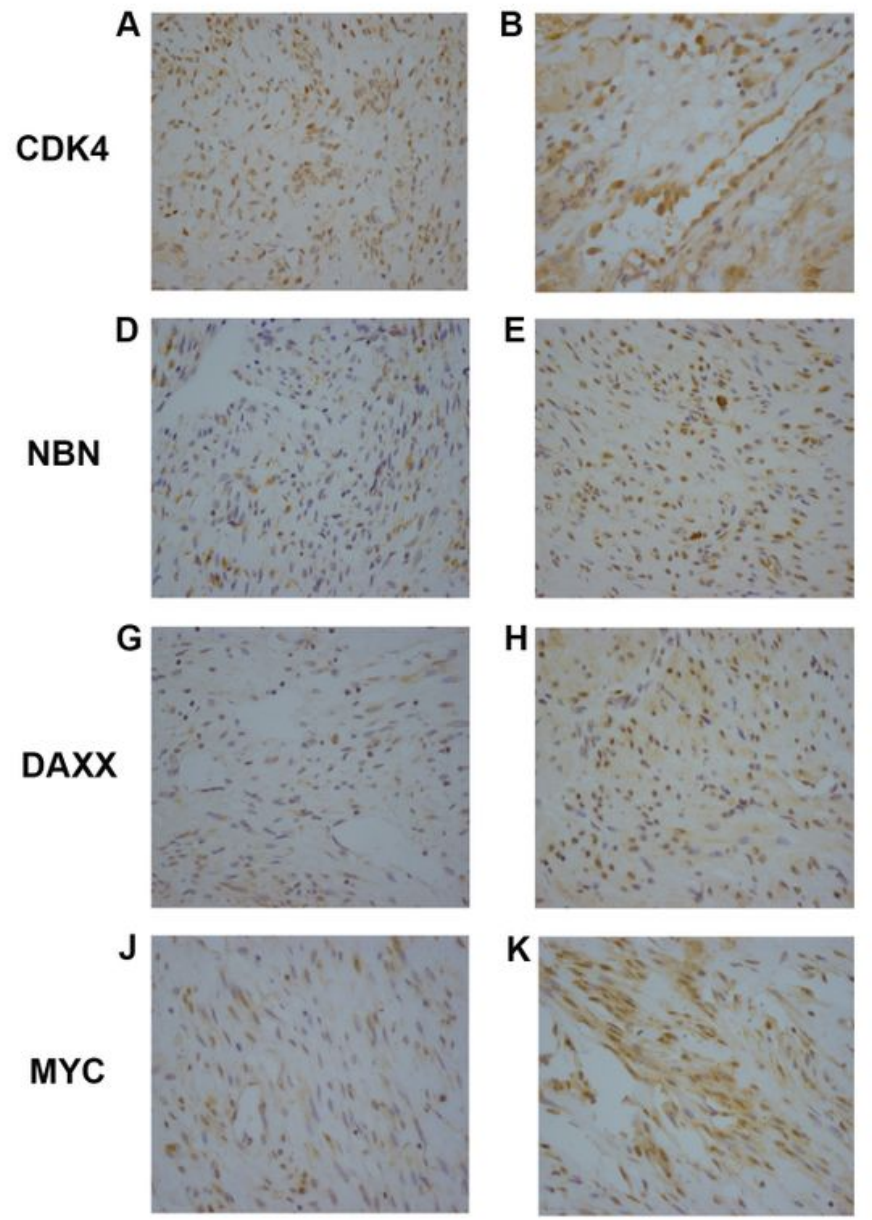

Leiomyoma

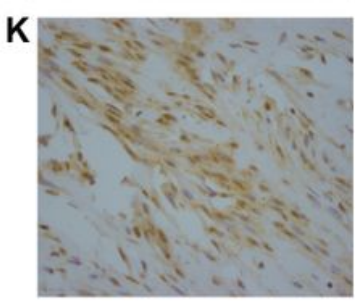

LPD
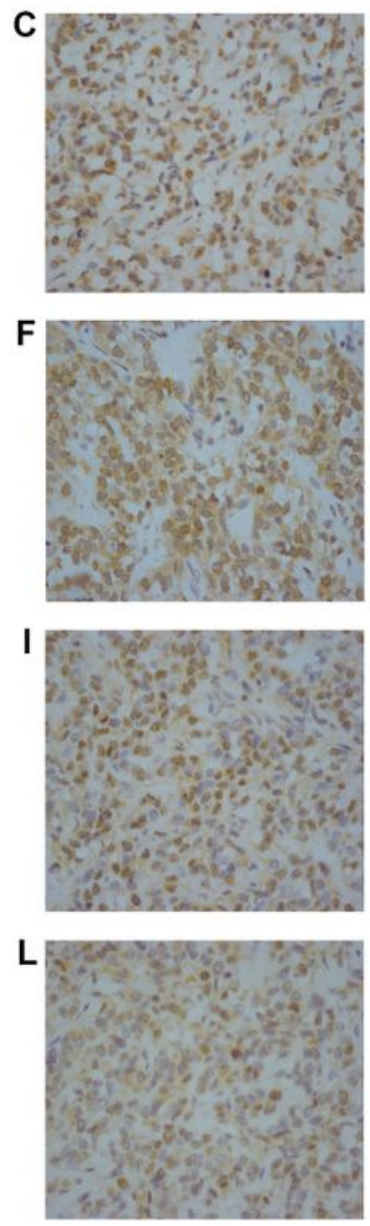

Leiomyosarcoma
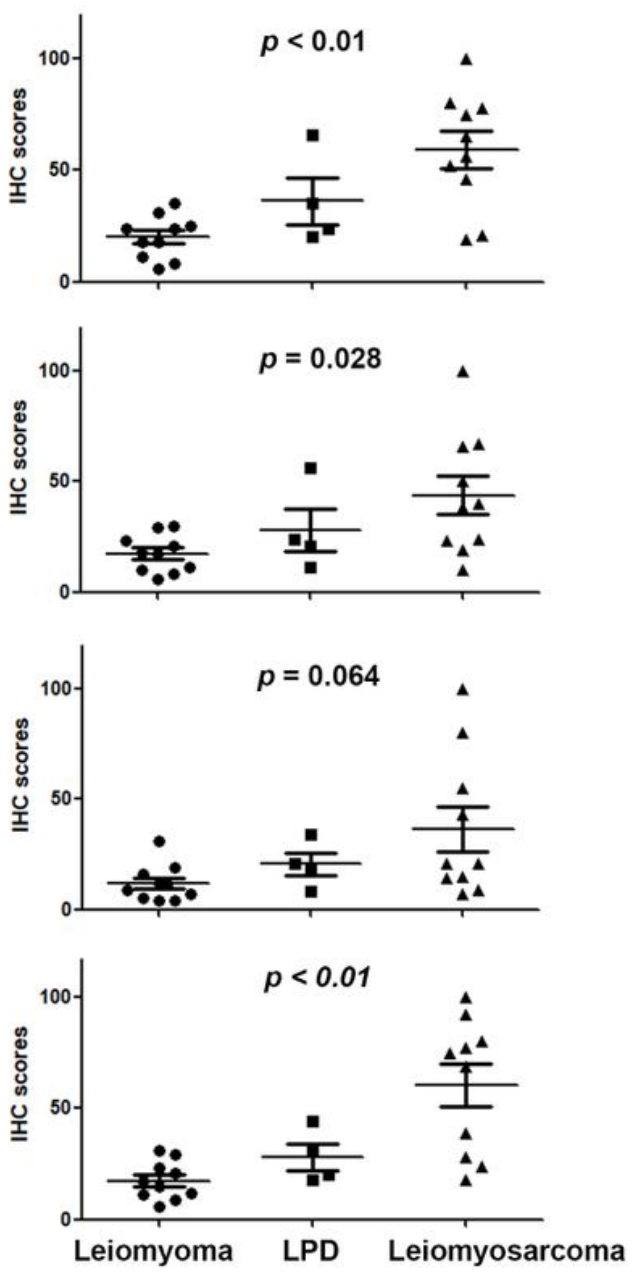

\section{Figure 4}

Immunohistochemistry staining analysis of CDK4, NBN, DAXX and MYC in leiomyoma, LPD and leiomyosarcoma, suggesting that LPD is an unusual intermediate between benign and malignant uterine smooth muscle tumors. 